\title{
Effects of temperature changes on maize production in Mozambique
}

\author{
L. Harrison ${ }^{1, *}$, J. Michaelsen ${ }^{1}$, C. Funk ${ }^{1,2}$, G. Husak ${ }^{1}$ \\ ${ }^{1}$ Department of Geography, Climate Hazards Group, UC Santa Barbara, Santa Barbara, California 93106, USA \\ ${ }^{2}$ U.S. Geological Survey/Earth Resources Observation and Science (EROS), Sioux Falls, South Dakota 57198, USA
}

\begin{abstract}
We examined intraseasonal changes in maize phenology and heat stress exposure over the 1979-2008 period, using Mozambique meteorological station data and maize growth requirements in a growing degree-day model. Identifying historical effects of warming on maize growth is particularly important in Mozambique because national food security is highly dependent on domestic food production, most of which is grown in already warm to hot environments. Warming temperatures speed plant development, shortening the length of growth periods necessary for optimum plant and grain size. This faster phenological development also alters the timing of maximum plant water demand. In hot growing environments, temperature increases during maize pollination threaten to make midseason crop failure the norm. In addition to creating a harsher thermal environment, we find that early season temperature increases have caused the maize reproductive period to start earlier, increasing the risk of heat and water stress. Declines in time to maize maturation suggest that, independent of effects to water availability, yield potential is becoming increasingly limited by warming itself. Regional variations in effects are a function of the timing and magnitude of temperature increases and growing season characteristics. Continuation of current climatic trends could induce substantial yield losses in some locations. Farmers could avoid some losses through simple changes to planting dates and maize varietal types.
\end{abstract}

KEY WORDS: Climate change - Temperature trends · Maize - Phenology - Degree-days · Mozambique

\section{INTRODUCTION}

\subsection{Effects of warming upon maize}

Water shortages and heat stress are two of the most important environmental factors limiting crop growth, development, and yield (Prasad \& Staggenborg 2008). Variation in water availablity (interannual or intraseasonal) is the prevalent limitation to crop production systems in most regions of the world-over $80 \%$ of total global agricultural land is rainfed (Easterling et al. 2007). As such, the discussion of potential hazards to crop production with climate change has mainly focused upon the risk of water shortages. However, gradual increases in growing season temperatures are also capable of substantial disruptions to production systems. The phenology (whole plant development rate) and physiology (functioning of internal processes) of many major crops are affected by ambient temperature. Through changes in phenology and physiology, warming is likely to shift the optimal times and locations for cropping. Problems for food security can arise when these agri-climatic shifts cross national bounds, or if communities lack means of adaptation to altered growing conditions. Because small changes to growing season temperatures in warm to hot regions could marginalize large swaths of farmland, developing countries whose best available production areas lie within these regions may be the first to face warming-driven challenges to food security.

Warmer growing season temperatures can directly reduce yields in two important ways. First, higher temperatures accelerate crop growth for crops whose phenology is predominantly regulated by temperature, such as maize. This reduces the time for plant and grain development, limiting the attainment of yield 
potential. Second, if extreme heat occurs during flowering, such as the maize 'silk-tasseling' phase, pollination may be inhibited and the development of grain may be prevented entirely. Additionally, temperature increases could accelerate plant development enough that the reproductive period, the development stage requiring the most water, would shift away from the typical wettest time of the cropping season-a problem for rainfed maize production systems.

The effect of temperature in reducing the length of the growth cycle, especially the grain filling phase, is the most important factor in explaining reduced yields at warmer temperatures (White \& Reynolds 2003). By accelerating crop development, elevated temperatures limit the amount of solar radiation received by the plant during each developmental stage. Aggregated over the entire growing period, less interception of solar energy is problematic. With less fuel to drive photosynthesis (i.e. the conversion of carbon dioxide to organic compounds), plant structures (such as leaves) tend to be smaller and less abundant, bringing matured plant biomass below potential levels (Sibma 1970, Duncan et al. 1973, Stone 2001, Scott et al. 2009). Therefore, independent of other stresses, the highest crop yields are attained when relatively mild temperatures maximize the total duration of growth (Muchow \& Bellamy 1991). In the subtropics this temperature-yield dependence is illustrated by the typical location of premier production zones in the coolest of regions with sufficient rainfall and soil fertility.

Maize yield is a function of number of grains (kernels) and grain weight. A strong relationship exists between grain weight and the duration of the reproductive (grain filling) phase (correlation of $\mathrm{r}=0.81$ by Cross 1975) (Daynard et al. 1971, Daynard \& Kannenberg 1976, Ottaviano \& Camussi 1981). Full potential grain weight is achieved when the rate of grain filling and the duration of the filling period are both at maximum. Over moderately high temperatures $\left(25\right.$ to $\left.32^{\circ} \mathrm{C}\right)$ the maximum grain filling rate is achieved. However, the high temperatures also accelerate plant development, causing the duration of the filling period to shorten. Because the enhanced filling rate cannot compensate for this temporal limitation, kernels cannot attain potential weight (Thorne \& Ford 1971, Spiertz 1974). At temperatures above $32^{\circ} \mathrm{C}$, starch production is impaired, slowing the filling rate (Singletary et al. 1994). The most substantial impacts to grain weight occur when the beginning of the reproductive period is exposed to temperatures above $32^{\circ} \mathrm{C}$ (Stone \& Nicolas 1995, 1998).

Heat or drought stress during the maize silk-tasseling phase (flowering and pollination) have been observed to reduce yields by as much as $7 \%$ per day of stress, a greater yield reduction than for all other potential climatic stresses (Shaw 1977). This yield impact is due to physiological stress, rather than the sensitivity of plant phenology to temperature discussed above. Fertilization necessitates a temporal overlap between the shedding of pollen by tassel and the emergence of silks (to intercept the pollen). Hot and dry weather both hastens pollen shed and delays silk emergence, narrowing the duration of co-occurrence. In addition, the ability of pollen to germinate on silks is greatly reduced at temperatures above $32^{\circ} \mathrm{C}$ (Basra 2000). The result is fewer kernels available for filling during the reproductive period that directly follows (Herrero \& Johnson 1980). Although climatic factors can cause severe yield reductions, their effects on silk-tasseling are difficult to identify because of the short duration of the period (Porter \& Semenov 2005).

Warming trends were deemed responsible for suppression of global agricultural productivity during the past $30 \mathrm{yr}$ in a study by Lobell \& Field (2007). They found that while improvements to agricultural technologies (and possibly $\mathrm{CO}_{2}$ fertilization) increased yields as a whole, the advancements were offset by negative plant responses to higher temperatures - an effect which will likely be exacerbated by increases in the mean or variability of current temperatures (Porter \& Semenov 2005, Lobell \& Field 2007). The largest negative impacts may occur in low latitude regions, where temperatures in many cereal production environments already approach plant thresholds (Easterling et al. 2007). Understanding historical temperature trends in a context meaningful for crop yields, such as for the major yield-affecting impacts discussed above, is important for identifying the effects that regional climatic changes have had on production. Trends observed in recent records can be used to anticipate effects in the near future, provided that regional warming trends do not change. Given higher confidence in temperature projections than precipitation for many regions, near future extrapolation of observed plant responses to warming (rather than to water stress) could cast light upon the types of hazards to plan for.

According to a recent study by the National Disaster Management Institute of Mozambique (INGC 2009), substantial warming has occurred over the past several decades. What is not known is how this warming has affected agriculture, since many regions lack an organized, well funded and long term agricultural research sector, and systematic collection of yield data or crop phenology observations are not available. In the case of Mozambique, such organisation in the agricultural sector was prevented by severe political turmoil during the civil war. For any region, the absolute measurement of yield changes due to heat stress is complicated by interactions between temperature and other important environmental inputs such as rainfall, solar radiation, and nutrient supply. For example, temperaturedriven increases to atmospheric evaporative demand 
can induce plant drought stress by decreasing soil moisture. Additionally, diurnal asymmetry of temperature changes can impact different plant physiological processes, and can have different effects on yield (Wardlaw et al. 1980, Peng et al. 2004). Deterministic crop models are increasingly used to deal with these complex interactions. Realistic model results depend on accurate information about field conditions, weather data, and agricultural management. As this detailed information becomes available and regional field experiments are integrated, crop models will become a useful tool for medium scale climate-yield analyses. Since this is not currently available, in the study we use the resource that is available in Mozambique (i.e. station temperature data) to discern historical changes to the types of heat stress presented above. With this information, the focus of future research or locationspecific adaptation efforts can be directed towards the most concerning and probable effects of warming to Mozambique production.

This study attempts to identify the magnitude, type, and spatial pattern of effects that observed warming has had on maize growth in Mozambique over the past 30 yr (1979/80-2008/09). Maize phenology for each growing season is modeled at 9 meteorological stations (Fig. 1) using daily minimum and maximum temperature observations and a growing degree-day accumulation method, where daily plant development is determined by average air temperature (Gilmore \& Rogers 1958, Cross \& Zuber 1972, McMaster \& Wilhelm 1997). Historical changes to maize phenology and observed temperature during the major phenological stages are quantified and tested for statistical significance at the $5 \%$ level. Using information on the major changes experienced at each location, regions of commonality, physical drivers of the observations, and applicable adaptation strategies are discussed.

\subsection{Mozambique climate and maize production}

The relatively close proximity of all regions of Mozambique to the heat reservoir of the southwest Indian Ocean maintains warm surface temperatures

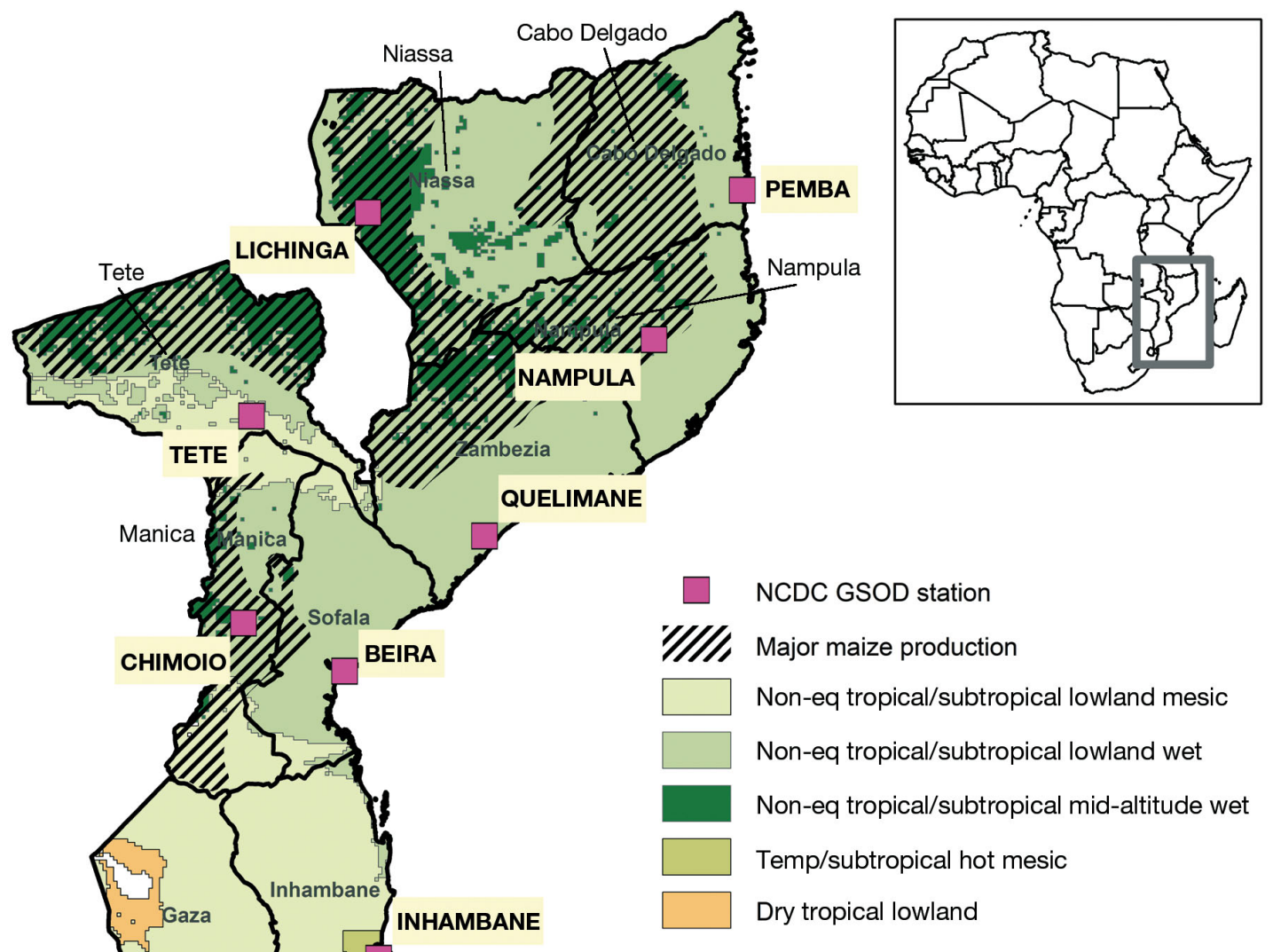

Fig. 1. Mozambique climate regions (Hartkamp et al. 2000) and major maize production areas 
year round (annual average temperature is $24^{\circ} \mathrm{C}$ ) (Griffiths 1972). Regional variations occur largely from differences in topography and latitude. In general, intense solar radiation produces higher temperatures in lower latitude regions. However, the coolest conditions nationwide are found in the northwestern plateau because of elevation gains (annual average temperature is 18 to $20^{\circ} \mathrm{C}$ ) (MICOA 2007). The hottest regions are the central Zambezi River Valley, the northern and central coast, and the southern inland Limpopo Basin (annual averages 24 to $26^{\circ} \mathrm{C}$ ) (MICOA 2007). These lowland zones are consistently heated by the flow of warm moist air from the Mozambique Channel, and in the case of the northern and central regions, also from subsiding air from the higher elevation regions in the west. The hottest time of the year is October through February, during the major cropping season. Growing season average temperature varies regionally between 21 and $29^{\circ} \mathrm{C}$, with monthly average daytime temperatures during the season reaching as high as $36^{\circ} \mathrm{C}$. Peak heat in inland regions is during the beginning of the growing season; in coastal regions it is midway through the season (Griffiths 1972). Relative humidity is high in most areas ( $70 \%$ annual mean), especially in summer in the Zambezi Valley and along the coast year round. Distance from the coast and elevation gains reduce humidity and allow for cooler nights. Diurnal temperature ranges vary regionally between 10 and $14^{\circ} \mathrm{C}$ (Griffiths 1972).

Rainfall during the major cropping season starts in southern Mozambique with the advection of moisture onshore by mid-latitude ridging systems (Tadross et al. 2005). This can occur as early as September, but the systems can be sporadic, often leading to long early season dry spells. Therefore most planting begins in the southern and central regions with the onset of more consistent precipitation between late October and early December. Planting in the north usually begins in mid to late December. The season generally ends first in southern Mozambique (March) and approximately 2 mo later in the north when the Inter Tropical Convergence Zone (ITCZ) retreats equatorward (Tadross et al. 2005). The longer duration of seasonal rains and a more consistent moisture supply make northern and central Mozambique the major areas of national maize production (annual average precipitation $800-1400 \mathrm{~mm}$ ), though growing by small land holders occurs throughout most of Mozambique. Highest maize yields $\left(1000 \mathrm{~kg} \mathrm{ha}^{-1}\right)$ are attained in the higher elevation areas of the northwest and central regions of the country (AFTS1 2006). Cooler temperatures maximize the duration of maize growth while the relief's orographic influence provides reliable, sufficient rainfall. The lowland central region supports lower maize yields of $600 \mathrm{~kg} \mathrm{ha}^{-1}$, with fertile flood- plain soil helping to alleviate some effects of the more difficult climate conditions. Maize yields in these areas are limited by frequent dry spells during the growing season, intermittent flooding, occasional heat stress, and shorter growth duration due to consistently high temperatures. Maize production in southern Mozambique is mostly limited to the areas of moderate rainfall along the coast (average annual precipitation $700 \mathrm{~mm}$; MICOA 2007).

\section{MATERIALS AND METHODS}

\subsection{Temperature data}

Temperature observations are from the National Climatic Data Center's Global Surface Summary of the Day (NCDC GSOD) archive. These were composed of daily minimum and maximum temperature data for growing seasons $1979 / 80$ to 2008/09. Of the 23 Mozambique stations in the NCDC GSOD archive, 9 were selected based upon temporal quality ( $>50 \%$ of the historical period with daily records). For a growing season year to be included in the analysis, temperature records had to be complete for at least $60 \%$ of the days, with no gaps longer than $17 \mathrm{~d}$. This upper limit of gap size is not representative of the overall character of the data; most years had gaps of $<7 \mathrm{~d}$. The percentage of data complete at each station for growing seasons used in the analysis (range $79-90 \%$ ) are presented in Table 1. To capture the growing season temperature characteristics at each station, 3rd order polynomial equations were fitted to the historical minimum and maximum temperature data. Gaps were filled using these smoothed climatological daily means, which were scaled to consider the $5 \mathrm{~d}$ of temperature records preceding and following each gap.

The 9 meteorological stations are distributed as follows: 3 stations are in the northern region, 4 in the central, and 2 in the southern region (Fig. 1). Three of these, Lichinga, Nampula, and Chimoio, are within areas of major national maize production. Maize growing environments in Mozambique fall into 4 major subtropical climatic zones: lowland wet (majority of the northern and central regions; 5 stations), lowland mesic (majority of the southern region and the central region Zambezi River Valley; 1 station), mid-altitude (northwestern plateau; 1 station), and temperate hot mesic (southern region coastal area; 2 stations) (Hartkamp et al. 2000). Spatial coverage is best in the northern region and declines southward where stations are concentrated along the coast. Though higher density coverage is desired, weak temperature gradients over much of the country allow for reasonable extrapolation of warming trends at the regional level. For the goals 
Table 1. Mozambique meteorological station characteristics. NCDC GSOD: National Climatic Data Center's Global Summary of the Day; GeoWRSI: US Geological Survey Geospatial Water Requirement Satisfaction Index; SOS: Start of season

\begin{tabular}{|c|c|c|c|c|c|c|c|c|c|c|}
\hline Station & $\begin{array}{l}\text { NCDC GSOD } \\
\text { ID No. }\end{array}$ & $\begin{array}{l}\text { Data com- } \\
\text { plete }(\%)^{\mathrm{b}}\end{array}$ & $\begin{array}{l}\text { Lat. } \\
\left({ }^{\circ} \mathrm{S}\right)\end{array}$ & $\begin{array}{l}\text { Long. } \\
\left({ }^{\circ} \mathrm{E}\right)\end{array}$ & $\begin{array}{l}\text { Elev. } \\
(\mathrm{m})\end{array}$ & $\begin{array}{l}\text { Rainfall }^{\mathrm{c}} \\
(\mathrm{mm})\end{array}$ & $\begin{array}{r}\text { Tempe } \\
\text { Min. } .^{\mathrm{c}}\left({ }^{\circ} \mathrm{C}\right)\end{array}$ & $\begin{array}{l}\text { rature } \\
\text { Max. } .^{\mathrm{C}}\left({ }^{\circ} \mathrm{C}\right)\end{array}$ & $\begin{array}{l}\text { GeoWRSI climato- } \\
\text { logical SOS }\end{array}$ & $\begin{array}{l}\text { Maize } \\
\text { variety }\end{array}$ \\
\hline Pemba & 672150 & 82 & 12.98 & 40.53 & 50 & 649 & 23.2 & 30.6 & Dec. 11th & ZM721 \\
\hline Lichinga $^{a}$ & 672170 & 84 & 13.30 & 35.23 & 1365 & 870 & 15.5 & 26.6 & Nov. 21st & ZM721 \\
\hline Nampula $^{a}$ & 672370 & 83 & 15.10 & 39.28 & 441 & 820 & 21.7 & 30.5 & Nov. 21st & ZM721 \\
\hline Tete & 672610 & 74 & 16.18 & 33.58 & 150 & 538 & 23.8 & 33.8 & Nov. 21st & ZM721 \\
\hline Quelimane & 672830 & 83 & 17.88 & 36.88 & 16 & 902 & 23.2 & 32.0 & Nov. 11th & ZM721 \\
\hline Chimoio $^{\mathrm{a}}$ & 672950 & 79 & 19.12 & 33.47 & 732 & 807 & 19.4 & 28.1 & Oct. 21st & ZM721 \\
\hline Beira & 672970 & 82 & 19.80 & 34.90 & 16 & 1043 & 23.7 & 31.0 & Oct. 21st & ZM721 \\
\hline Inhambane & 673230 & 79 & 23.87 & 35.38 & 15 & 550 & 22.3 & 30.8 & Nov. 11th & ZM421 \\
\hline Maputo & 673410 & 90 & 25.92 & 32.57 & 44 & 524 & 22.0 & 29.6 & Nov. 11th & ZM421 \\
\hline
\end{tabular}

of this study, the 9 stations of the NCDC GSOD dataset provide an adequate representation of temperature regimes in maize growing areas of Mozambique. Station details are provided in Table 1.

\subsection{Varietal growth requirements}

Maize varietal types are typically chosen for planting by the average number of days required to progress from sowing to physiological maturity. This length of time completes the transition of a seed to a fully developed plant with grain growth complete and yield established. Ideally the length of growing period is well-matched to the duration of seasonal rains to avoid water stress and reach maximum yield potential. Resistance to disease, drought, and low soil fertility, as well as the price and availability of seed are other major factors that influence management decisions (Upton 1987).

This study models 2 maize varieties currently grown in southeastern Africa: International Maize and Wheat Improvement Center (CIMMYT) open pollinated varieties (OPV) ZM721 (Institute for Agricultural Research of Mozambique [IIAM] Tsangano) and ZM421 (IIAM Djandza). ZM721, a late-maturing type, is modeled for stations in northern and central Mozambique. Due to warm growing season temperatures, typical total growth duration (days to maturity) of ZM721 in these regions is between 100 to 120 d. ZM421, an earlymaturing drought tolerant variety is modeled at stations in southern Mozambique. Its total growth duration is approximately $90 \mathrm{~d}$. The accumulated growing degree-days required for each variety to reach the reproductive period and physiological maturity are calculated from CIMMYT regional field tests and the average growing season temperatures at each station.

\subsection{Modeling development}

Crop phenology is modeled using the concept of thermal time, where daily development is driven solely by air temperature. This methodology is often referred to as growing degree-day accumulation, and is the basis of most major crop models (McMaster \& Wilhelm 1997, Ritchie et al. 1998). In this method, for each day that the average temperature (mean of the minimum and maximum temperature) is above a minimum and below a maximum crop-specific temperature, development is tallied daily in the form of degree-days $\left({ }^{\circ} \mathrm{C} \mathrm{d}^{-1}\right)$. This study uses a similar thermal time modeling approach to that of the CERES-Maize (Crop Environment Resource Synthesis) model (Ritchie et al. 1998), a widely used deterministic crop model (Fig. 2). In this model, daily maize development increases linearly from a base temperature of $8^{\circ} \mathrm{C}$ to an optimal temperature of $34^{\circ} \mathrm{C}$. To represent the slowing of photosynthesis at high temperatures, the development rate quickly linearly decreases to zero between the optimal temper-

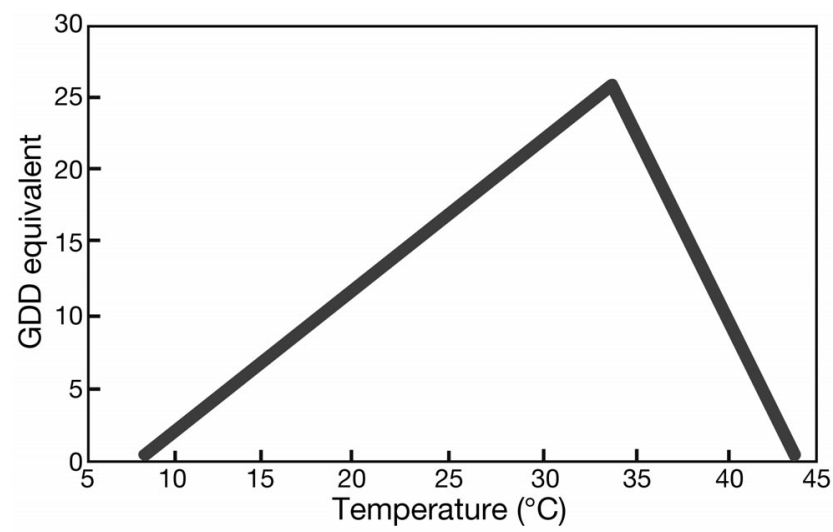

Fig. 2. Plant development progresses as a function of mean daily temperature, with fastest development at $34^{\circ} \mathrm{C}$. Growing degree-days (GDD) are accumulated daily to model phenology 
ature of $34^{\circ} \mathrm{C}$ and the maximum temperature of $44^{\circ} \mathrm{C}$. Fastest crop growth, and consequently shortest growth duration, therefore occurs when average air temperatures are consistently near $34^{\circ} \mathrm{C}$.

The maize daily development model requires 3 inputs: start of season (SOS) date and daily minimum and maximum temperature. The SOS for each station is held constant through the time series and is the climatological average computed by the US Geological Survey (USGS) Geospatial Water Requirement Satisfaction Index (GeoWRSI). GeoWRSI determines SOS by a cumulative precipitation accounting method, requiring $25 \mathrm{~mm}$ of rainfall in 1 dekad (10 d period) followed by 2 dekads of rainfall summing to at least $20 \mathrm{~mm}$ (Senay \& Verdin 2003). Though earlier or later planting is feasible, the average of SOS dates determined by this method represents the type of local knowledge a farmer would have for making planting decisions - the typical date when consistent rainfall begins. Station SOS dates are provided in Table 1.

\subsection{Measures of phenology and heat stress exposure}

The objective was to identify historical changes to the prevalence of the three major types of heat stress: Reduced time to maturation, reduced time for grain filling, and exposure to high temperatures during low physiological tolerance. For each growing season 13 representative measures were computed (Table 2). These include the duration from sowing until the reproductive period, the duration of the reproductive (grain filling) period, and the combination of these two (time to maturation). Variety-specific growing degreeday requirements were used to stratify each growing season by these phenological stages. The average daily minimum, maximum, and mean temperature were then determined for each stage. To assess plant exposure to acute heat stress during grain development, the 90th percentile daytime temperature during the reproductive period was calculated.

\subsection{Trend analysis}

At each station, changes to the 13 measures over the period 1979/80 to 2008/09 were quantified with linear regression and Sen's slope (Sen 1968) trend analyses. The slope values and statistical significance at the 0.05 level are reported. Using two different trend analysis methods helps with gauging confidence in results when trends from each agree, more confidence can be had in their authenticity. Sen's slope method is a nonparametric approach frequently used for environmental data analysis because it is robust to missing data
Table 2. Measures of growing season temperature and maize phenology

1. Mean average temperature before reproductive period $\left({ }^{\circ} \mathrm{C}\right)$

2. Mean minimum temperature before reproductive period $\left({ }^{\circ} \mathrm{C}\right)$

3. Mean maximum temperature before reproductive period $\left({ }^{\circ} \mathrm{C}\right)$

4. Days to start of reproductive period

5. Mean average temperature during reproductive period $\left({ }^{\circ} \mathrm{C}\right)$

6. Mean minimum temperature during reproductive period $\left({ }^{\circ} \mathrm{C}\right)$

7. Mean maximum temperature during reproductive period $\left({ }^{\circ} \mathrm{C}\right)$

8. Number of days in reproductive period

9. 90th percentile maximum temperature during reproductive period $\left({ }^{\circ} \mathrm{C}\right)$

10. Growing season average mean temperature $\left({ }^{\circ} \mathrm{C}\right)$

11. Growing season average minimum temperature $\left({ }^{\circ} \mathrm{C}\right)$

12. Growing season average maximum temperature $\left({ }^{\circ} \mathrm{C}\right)$

13. Days from sowing to physiological maturity

and outliers (Gilbert 1987). In this approach, the trend is estimated by taking the median value of the slopes for all combinations of data pairs (in this case, a phenological or temperature measure for each growing season). A Z-statistic is used to place confidence intervals around this value; statistical significance is achieved if a slope of zero does not fall within the bounds. Significance testing was prevented in some cases by too many matching slopes, such as those created by the measures with units of whole days and overall small variance (too few years of useable data). The trend analysis results for changes to growing season duration and average temperature are presented in Table 3. Statistically significant phenological trends and implications for maize production are summarized in Table 4.

Table 3. Linear regression (LR) and Sen's slope (Sen) trend coefficients are multiplied by the time series length to present the magnitude of change to growing season length and average temperature at stations (1979/80-2008/09). ${ }^{*}$ Significant $(\mathrm{p}<0.05)$

\begin{tabular}{|lcccc|}
\hline Station & \multicolumn{2}{c}{$\begin{array}{c}\text { Growing season } \\
\text { length }(\mathrm{d})\end{array}$} & \multicolumn{3}{c|}{$\begin{array}{c}\text { Season average } \\
\text { temperature }\left({ }^{\circ} \mathrm{C}\right) \\
\text { LR }\end{array}$} & Sen & LR & Sen \\
\hline Pemba & $-3.6^{*}$ & -3.3 & $0.6^{*}$ & $0.6^{*}$ \\
Lichinga $^{\mathrm{a}}$ & -0.9 & 1.5 & 0.0 & 0.0 \\
Nampula $^{\mathrm{a}}$ & $-6.6^{*}$ & -7.2 & $1.2^{*}$ & $1.2^{*}$ \\
Tete & 4.2 & 3.0 & -0.9 & -0.3 \\
Quelimane $_{\text {Chimoio }}^{\mathrm{a}}$ & $-6.0^{*}$ & $-6.6^{*}$ & $1.5^{*}$ & $1.8^{*}$ \\
Beira & -6.9 & $-6.0^{*}$ & $1.2^{*}$ & $1.8^{*}$ \\
Inhambane & $-4.5^{*}$ & -5.1 & $0.9^{*}$ & $1.2^{*}$ \\
Maputo & -3.3 & -6.0 & 0.9 & 1.5 \\
aWithin area of major national maize production & \\
\hline
\end{tabular}


Table 4. Statistically significant changes to maize phenology (1979/80-2008/09) at Mozambique stations and implications for maize production

\begin{tabular}{|llcll}
\hline Phenological trend & Cause & Potential yield impact & Station \\
\hline $\begin{array}{c}\text { Decreased time from } \\
\text { planting to start of the } \\
\text { reproductive period }\end{array}$ & $\begin{array}{c}\text { Early season } \\
\text { temperature } \\
\text { increases }\end{array}$ & $\begin{array}{c}\text { Crop water requirements are at maximum earlier in } \\
\text { the season; yield risk if consistent rainfall does not }\end{array}$ & $\begin{array}{l}\text { Pemba } \\
\text { Nampula } \\
\text { Quelimane } \\
\text { Chimoio }\end{array}$ \\
also start early & & Beira \\
Decreased duration of & Mid to late season & Grain weight decreases; yield reduction & Maputo \\
the reproductive period & temperature increases & & Nampula \\
$\begin{array}{c}\text { Decreased time to } \\
\text { maturity }\end{array}$ & Temperature & Plant biomass decreases; yield reduction & Quelimane \\
& increases during & & Pemba \\
& entire season & & Nampula \\
& & & Quelimane \\
& & & Chimoio \\
\end{tabular}

\section{RESULTS AND DISCUSSION}

\subsection{Onset of reproductive period}

Increases in early growing season temperature between 1979/80 and 2008/09 indicate maize development rates have likely accelerated at most of the Mozambique stations, causing the first day of the reproductive period to advance on average $4 \mathrm{~d}$ over this time range (Fig. 3a). This corresponds to approximately $7 \%$ of the typical length of the maize vegetative stage. Location-specific results vary between 2 and $6 \mathrm{~d}$. These changes were found to be significant $(p<0.05)$ for 6 of the 9 stations, and are directly attributable to increases in average mean temperature between sowing and the start of the reproductive period (Table 4). Average mean temperature increases were driven by significant increases in both minimum and maximum temperature at 3 of the 6 stations (Quelimane, Chimoio and Beira). At the Pemba and Maputo stations, significant trends in minimum temperature were the cause. At the Nampula station, the accelerated development was caused by significant increases in maximum temperature amounting to $2.4^{\circ} \mathrm{C}$ over the $30 \mathrm{yr}$ period.

The largest decreases in the number of days from sowing to the reproductive period were found at central region stations Nampula, Beira, Chimoio, and Quelimane, where early season average temperature increased over the $30 \mathrm{yr}$ period by more than $1.5^{\circ} \mathrm{C}$. At Chimoio, Beira, and Pemba, the magnitude of phenological changes was larger than half the historical variability (range of reproductive period start dates at these stations was 9,7 , and $4 \mathrm{~d}$, respectively). These findings suggest maize crops are reaching the reproductive period, the period of maximum water need, increasingly earlier in the season than they were in the past. Silk-tasseling, the brief but highly sensitive de- velopment phase just before the reproductive period, would also be occurring earlier. While the inter-annual timing of peak seasonal rainfall has been inconsistent enough to permit this phenological change to likely go unnoticed, continued warming could create a problem. If the reproductive period continues to advance at the rate observed, asynchrony could occur between the typical seasonal rainfall maxima and these moistureneedy plant phases (Fig. 4). For example, if the trend identified at Chimoio continues (earlier reproductive period start by $0.23 \mathrm{~d} \mathrm{yr}^{-1}$ ), by the mid 21 st century the reproductive period start date would be $10 \mathrm{~d}$ earlier than the historical average, placing it 5 to $6 \mathrm{~d}$ outside the historical range. This may place the maize silktasseling phase and the beginning of the grain filling period in a hot and, if before the peak of seasonal rainfall, also dry time of the growing season.

\subsection{Maturation}

Linear regression disclosed significant $(p<0.05)$ decreasing trends in time to maize maturation at 4 of the 9 stations in Mozambique (Table 4). Sen's slope method confirmed significance at Quelimane, and additionally identified a significant phenological change at Chimoio. Trend magnitudes were similar for both methods at these 5 locations. Increases in the average temperature between sowing and maturity were responsible (Fig. 3c). Over the $30 \mathrm{yr}$ span, coastal stations experienced an average $1.3^{\circ} \mathrm{C}$ increase in minimum temperature. Maximum temperature increases greater than $2^{\circ} \mathrm{C}$ were identified at the central region stations Quelimane (coastal) and Nampula (inland) (Fig. 5). The largest significant increases to average growing season temperature occurred at central region stations, causing declines in total growth duration 
between 5 and $7 \mathrm{~d}$. These changes amount to 5 to $7 \%$ of typical growth duration, as the region's hot summer climate already induces short maize growing periods. Based upon these trends, maize production areas in central Mozambique appear to be those most affected by warming-induced changes to phenology.

\subsection{Heat stress and the reproductive period}

Significant temperature and phenological changes during the reproductive period suggest warming could be suppressing grain filling in parts of central Mozambique. The length of the reproductive period controls yield by limiting the amount of time the plant has to convert assimilates to starch and fill grain. A shorter duration results in lower grain mass. Results show the duration of this period significantly decreased at Quelimane and Nampula by $5 \%$ over the $30 \mathrm{yr}$ period. The phenological change at these locations is caused by significant increases in average temperature during the reproductive period. No significant changes were identified at the remaining 7 stations. One explanation could be the timing of the reproductive period in relation to intraseasonal climatic variability. Since the reproductive period occurs during the rainiest part of the growing season, more frequent cloud cover and higher water vapor content of local air masses during this time may inhibit strong warming. It should be noted that while no significant changes to reproductive period length were found at stations other than Quelimane and Nampula, significant increases in minimum temperature during the period were found at Pemba, Chimoio, Beira, and Inhambane. Combined with the more intense warming trends earlier in the growing season, a pattern potentially emerges. As the reproductive period begins earlier and is exposed to higher temperatures, especially at night, changes to grain filling duration may begin to surface (Fig. 3b).

At Nampula, Quelimane, and Beira the $30 \mathrm{yr}$ average hottest daytime temperatures during the reproductive period (90th percentile maximum temperature) ranged between 32.9 and $35.5^{\circ} \mathrm{C}$. Significant increases of 1.2 to $1.8^{\circ} \mathrm{C}$ were identified at these stations. The 90th percentile maximum temperature does not directly relate to maize growth. Rather, it represents the more adverse of daytime conditions plants are exposed to during a sensitive period of development. Near exponential increases in atmospheric evaporative demand with higher temperatures can result in daytime plant-
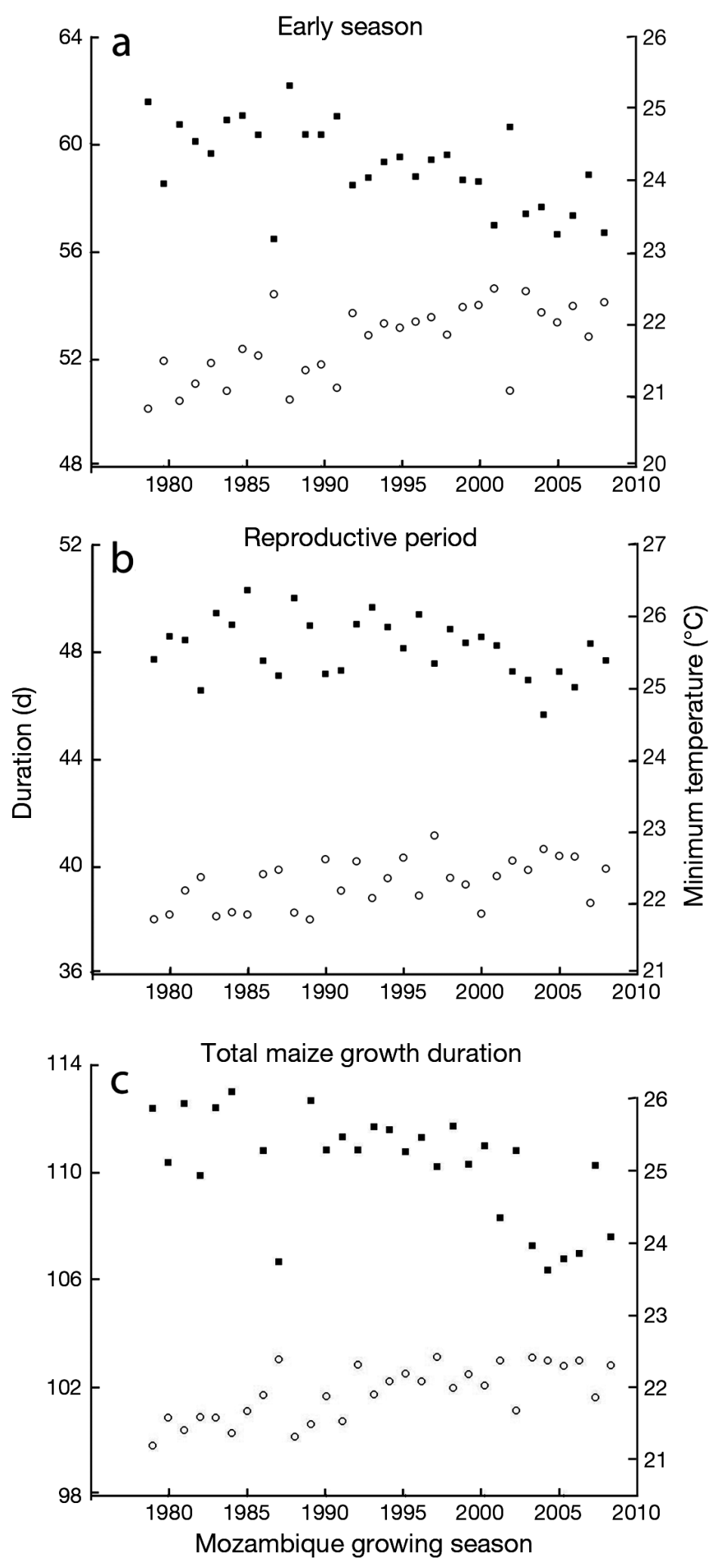

Fig. 3. Historical trends of Mozambique maize growth duration ( $\square$ ) and minimum temperature (o), stratified by phenological period: (a) sowing to start of reproductive period, (b) reproductive (grain filling) period, and (c) sowing to physiological maturity 


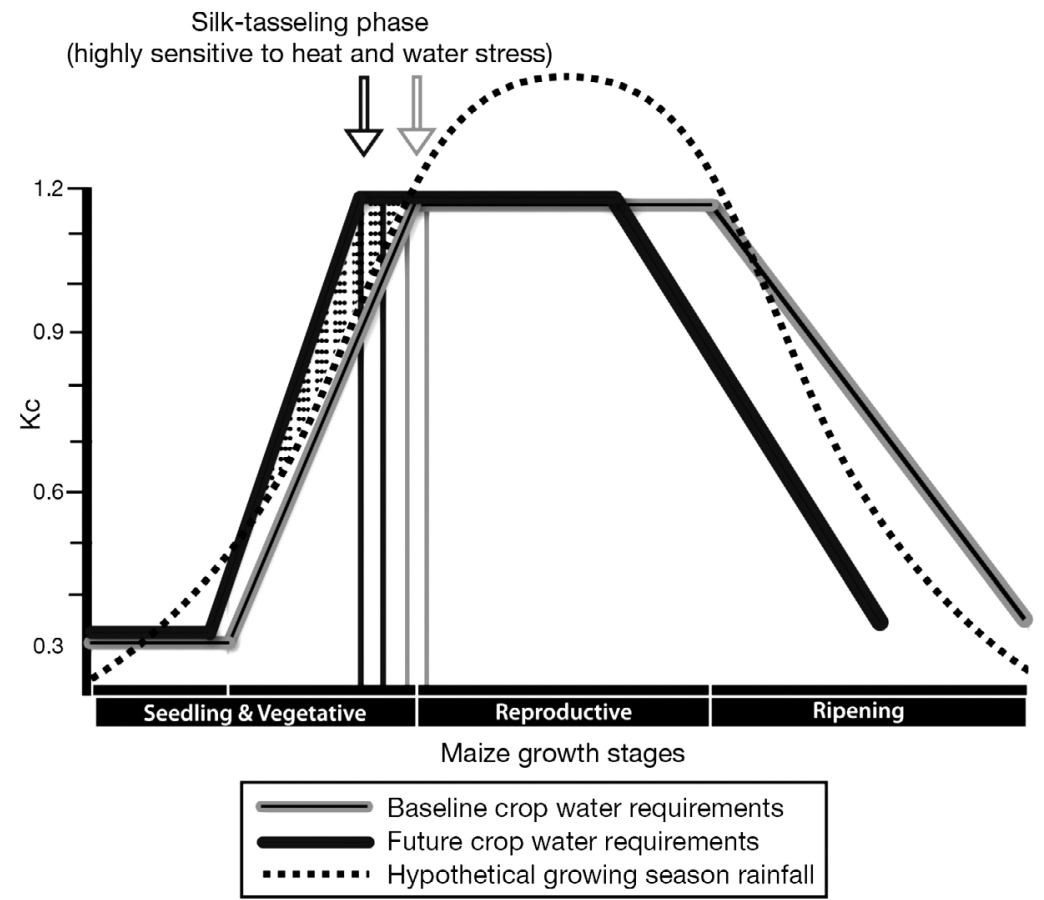

Fig. 4. FAO crop water requirement coefficient (Kc) values on the $y$-axis represent maize water needs from planting until harvest ( $x$-axis). The entire reproductive (grain filling) period requires the most moisture $(\mathrm{Kc}=1.2)$; rainfed production requires its temporal alignment with the peak of seasonal rainfall. Continued warming may cause an asynchrony large enough to threaten yields, particularly from exposure of the silk-tasseling phase to hot, dry conditions

water deficits, a particular problem for the water needy reproductive period. Acting in concert, high daytime temperatures (above $32^{\circ} \mathrm{C}$ ) raise plant tissue temperatures above threshold levels, damaging yieldinfluencing mechanisms (Hall 2001). The magnitude of hottest daytime temperature increases at these already hot locations indicates that the stress-tolerance of maize production in central Mozambique would be increasingly tested if the character of observed warming persists.

\subsection{Inconsistencies at Lichinga and Tete stations}

The results at Lichinga and Tete (Table 3) were inconsistent with the strong significant trends found at most of the stations. At Lichinga only one significant change to temperature or phenology was identified: a decrease in early season maximum temperature. Though only 13 growing season years were available, these were well distributed across the $30 \mathrm{yr}$ span. Lichinga is on the mid-altitude plateau in the far northwestern region of Mozambique. At 1635 m elevation, it is the highest station by nearly a kilometer. Suppression of historical warming here is likely due to a less direct climatic influence of the warm Indian Ocean, as illustrated by its cool summers $\left(20^{\circ} \mathrm{C}\right.$ average $)$. High annual precipitation totals of near $1200 \mathrm{~mm}$ also indicate different climatic drivers than the majority of the country, where the average is $600 \mathrm{~mm}$.

Significant decreasing trends during the reproductive period are found at Tete station. Results show a decrease in average maximum and 90th percentile daytime temperatures, and subsequently a lengthened duration of the period. No significant changes in minimum temperature were identified. Such dissimilarity with the rest of the stations may be due to limited data availability at this station. These results are mostly driven by data between 1979 and 1996; from 1997 to 2001 the data appear more similar to the other stations. A lack of 2002-2008 data at Tete station prevents further analysis. The exception is the 1998/99 growing season, when daytime temperatures appear to have been roughly $2^{\circ} \mathrm{C}$ cooler than normal (data not shown). In this year a strong La Niña event brought well above average rainfall to central and southern Mozambique. Enhanced cloud cover likely caused this sharp drop from normal surface temperature at Tete. Consequently, the ideal climate conditions increased yield and planted area, creating a nationwide maize surplus of $51850 \mathrm{t}$ (MNA 1998). This outlier exhibits how connections between historical surface temperature anomalies and interannual climate drivers could potentially improve regional temperature forecasting at the sub-seasonal level.

\subsection{Spatial coherence}

Interesting spatial patterns arise when considering minimum or maximum temperatures as the driver of the historical phenological changes. The results show increasing minimum temperature trends at 5 stations. Increasing trends in maximum temperature occurred at 3 stations, Nampula, Quelimane, and Beira (Fig. 5), which are all located between 15 and $19^{\circ} \mathrm{S}$ and within $150 \mathrm{~km}$ of the coast. This suggests that global climate changes have affected surface temperature controls differently here than the rest of the country. The spatial coherence of results also argues against the likelihood that changes in station instruments or data collection procedures over time are the cause of trends (Horton 1995). For example, changes in observing time 
or the way instruments are sheltered can have an asymmetric effect on maximum and minimum temperature records (Parker 1994). A recent climate change analysis by the INGC (2009) also found prominent warming trends in the central region.

Because Mozambique's seasonal climate characteristics and interannual precipitation fluctuations have historically been tightly coupled with Indian Oceanatmospheric interactions, it is likely that the observed station increases are caused by ocean surface warming. A strong covariance exists between south-central Indian Ocean $\left(0\right.$ to $15^{\circ} \mathrm{S}, 60$ to $\left.90^{\circ} \mathrm{E}\right)$ sea surface temperatures and global temperature $(\mathrm{r}=0.82)$, both of which have risen dramatically since the 1980s (Funk et al. 2008). Additionally, the recent rise of tropical Indian Ocean sea surface temperatures to their highest value in $120000 \mathrm{yr}$ indicates that the strong temperature and phenological trends identified in this study are likely to continue with the progression of global climate change (Hansen et al. 2006).

\subsection{Implications of continued warming}

Climate models project that observed warming will continue. By 2081-2100, temperatures could be 5 to $6^{\circ} \mathrm{C}$ above 20th century averages, with strongest increases in

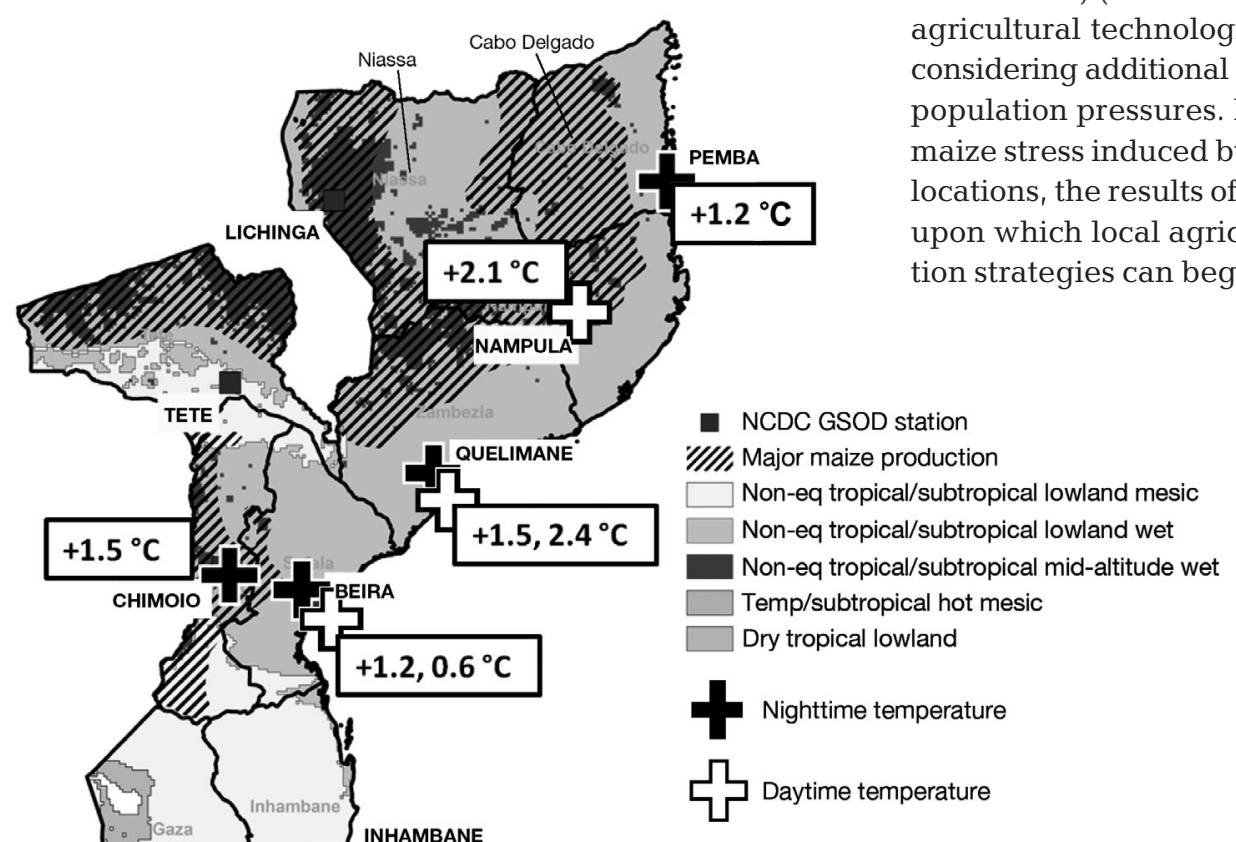

Fig. 5. Magnitude of significant $(p<0.05)$ changes in growing season mean minimum and maximum temperature (1979/80-2008/09). For Quelimane and Beira, values are nighttime, daytime the central region during the September-November months (INGC 2009). The relevance of results is best demonstrated in this context. Impacts to regional yields will be a function of growing season characteristics and the timing and magnitude of temperature increases. Several climate change modeling studies have attempted to quantify the direct impact of warming upon maize yields. For example, a $17 \%$ yield decline per $3^{\circ} \mathrm{C}$ increase in average growing season temperature was identified by Brown \& Rosenberg (1997) for the central United States. Lobell \& Asner (2003) found a similar decline for every $1^{\circ} \mathrm{C}$ increase. By applying the more conservative estimate of Brown \& Rosenberg (1997), we can make a general pass at estimating what observed warming could mean for Mozambique yields. If observed significant station warming trends were to continue through the first half of the 21st century, maize yields in Mozambique could decrease by 6 to $14 \%$ solely from changes to growing season average temperature. However, a full-scale analysis considering characteristics of Mozambique farmland and climate (historical and projected) would provide a more realistic estimate of projected changes to yield with climate change.

Because of limited rural access to agricultural technologies such as fertilizer, pesticides, and animal traction, Mozambique maize yields are presently far below potential levels ( $0.9 \mathrm{t} \mathrm{ha}^{-1}$ actual average vs. potential 5.0 to $6.5 \mathrm{t} \mathrm{ha}^{-1}$ ) (AFTS1 2006). Rapid changes in access to agricultural technologies are needed, especially when locations, the results of this study provide a springboard upon which local agricultural investments and adaptation strategies can begin to be prioritized.

\subsection{Sub-regional adaptation strategies}

Farmers could proactively respond to some of the future threats identified here with modest changes in their current practices. For example, the expected shift of plant water needs away from (before) the typical peak of seasonal rainfall could be prevented by an equal delay in planting. This would lessen exposure to drought during silk-tasseling and provide some escape from the observed and projected warming concentrated during the early part of 
the growing season. As precipitation projections suggest that rainfall during the late season will increase, delayed planting could be a relatively safe strategy for food production.

Planting maize varieties of longer growth duration than traditionally used could be another potential method of adaptation in the future. This would elongate an otherwise shortened duration of maize growth so that maximal use of seasonally available soil moisture occurs. The use of longer cycle varieties, with delayed stages, could also contribute to reducing the timing shift of water needs. This study finds that experimentation with longer duration varieties could be especially beneficial to central region farmers. The observed warming of daytime temperatures past critical maize thresholds in this region also points to the need for farmer access to improved varieties with higher tolerance to climatic stress during pollination and grain development.

\section{CONCLUSION}

Using a linear relationship of daily crop development and temperature, this study has translated observed warming into a context meaningful to maize production. By using station temperature data and focusing the analysis upon local growing seasons, the particular forms of heat stress influential to local maize yields are identified. Given the projected continuation of climate warming, this information can be used for determining optimal local adaptation strategies. Results suggest that warming between 1979/80 and 2008/09 produced significant changes to maize phenology and heat stress exposure in Mozambique. The historical trends are strong and spatially coherent. At most stations the strongest warming occurred during the first half of the growing season, increasing risks for seedling survival and maize pollination. At 5 of the 9 stations, warming occurred throughout the growing season, significantly compressing the duration of maize growth. Strong links between the end of season yield, time to maturity, and grain filling duration, suggest that temperature changes are introducing new and substantial threats to maize production in Mozambique.

Acknowledgements. This research was supported by the U.S. Agency for International Development Famine Early Warning System Network under U.S. Geological Survey Cooperative Agreement \#G09AC00001 and the National Aeronautics and Space Administration under Precipitation Science Grant \#NNX07AG266. We thank these agencies for their support. We also thank and acknowledge Blessing Siwela and Tamuka Magadzire of the SADC RRSU for the major Mozambique production zones spatial data and John MacRobert of CIMMYT for the maize varietal information. Also thanks to three anonymous reviewers, whose comments improved the quality of the manuscript.

\section{LITERATURE CITED}

AFTS1 (2006) Stimulating smallholder agricultural growth. Report No. 32416-MZ, World Bank. http://siteresources. worldbank.org/MOZAMBIQUEEXTN/Resources/Moz_ AG_Strategy.pdf

Basra AS (2000) Crop responses and adaptations to temperature stress. Food Products Press, New York

Brown RA, Rosenberg NJ (1997) Sensitivity of crop yield and water use to change in a range of climatic factors and $\mathrm{CO}_{2}$ concentrations: a simulation study applying EPIC to the central USA. Agric For Meteorol 83:171-203

Cross HZ (1975) Diallel analysis of duration and rate of grain filling of seven inbred lines of corn. Crop Sci 15:532-535

Cross HZ, Zuber MS (1972) Prediction of flowering dates in maize based on different methods of estimating thermal units. Agron J 64:351-355

Daynard TB, Kannenberg LW (1976) Relationships between the length of actual and effective grain filling periods and the grain yield of corn. Can J Plant Sci 56:237-242

Daynard TB, Tanner JW, Duncan CP (1971) Duration of grain filling period and its relationship to grain yield in corn, Zea mays L. Crop Sci 11:45-48

> Duncan WG, Shaver DL, Williams WA (1973) Insolation and temperature effects on maize growth and yield. Crop Sci 13:187-191

Easterling WE, Aggrawal PK, Batima P, Brander KM and others (2007) Food, fibre, and forest products. In: Parry ML, Canziani OF, Palutikof JP, Hanson CE, van der Linden PJ (eds) Climate change 2007: impacts, adaptation and vulnerability. Contribution of Working Group II to the Fourth Assessment Report of the IPCC. Cambridge University Press, Cambridge, p 273-313

Funk C, Dettinger MD, Michaelsen JC, Verdin JP, Brown ME, Barlow M, Hoell A (2008) Warming of the Indian Ocean threatens eastern and southern African food security but could be mitigated by agricultural development. Proc Natl Acad Sci USA 105:11081-11086

Gilbert RO (1987) Statistical methods for environmental pollution monitoring. van Nostrand Rienhold Company, New York

Gilmore ECJ, Rogers JS (1958) Heat units as a method of measuring maturity in corn. Agron J 50:611-615

Griffiths JF (1972) Mozambique. In: Griffiths JF (ed) Climates of Africa, Vol 10. Elsevier, New York, p 389-401

Hall AE (2001) Crop responses to environment. CRC Press, LLC, Boca Raton, FL

Hansen J, Sato M, Ruedy R, Lo K, Lea DW, Medina-Elizade M (2006) Global temperature change. Proc Natl Acad Sci USA 103:14288-14293

Hartkamp AD, White JW, Aguilar AR, Banziger M, Srinivasan G, Granados G, Crossa J (2000) Maize production environments revisited: a GIS-based approach. CIMMYT, Mexico City

> Herrero MP, Johnson RR (1980) High temperature stress and pollen viability of maize. Crop Sci 20:796-800

- Horton B (1995) Geographical distribution of changes in maximum and minimum temperatures. Atmos Res 37:101-117

INGC (2009) Main Report. National Disaster Management Institute (INGC), Maputo

Lobell DB, Asner GP (2003) Climate and management contributions to recent trends in U.S. agricultural yields. Science 299:1032

Lobell DB, Field CB (2007) Global scale climate-crop yield relationships and the impacts of recent warming. Environ Res Lett 2:014002-014008

McMaster GS, Wilhelm WW (1997) Growing degree-days: 
one equation, two interpretations. Agric For Meteorol 87:291-300

MICOA (Ministry for the Co-ordination of Environmental Affairs) (2007) National adaptation programme of action: Mozambique. Ministry for the Coordination of Environmental Affairs, Maputo

MNA (1998) Positive prediction for food harvest. Mozambique News Agency, AIM Reports, London

Muchow RC, Bellamy JA (eds) (1991) Climatic risk in crop production: models and management for the semiarid tropics and subtropics. CAB International, Wallingford, UK

Ottaviano E, Camussi A (1981) Phenotypic and genetic relationships between yield components in maize. Euphytica 30:601-609

Parker DE (1994) Effects of changing exposure of thermometers at land stations. Int J Climatol 14:1-33

Peng S, Huang J, Sheehy JE, Laza RC and others (2004) Rice yields decline with higher night temperature from global warming. Proc Natl Acad Sci USA 101:9971-9975

Porter JR, Semenov MA (2005) Crop responses to climatic variation. Philos Trans R Soc Lond B Biol Sci 360:2021-2035

Prasad PVV, Staggenborg SA (2008) Impacts of drought and/or heat stress on physiological, developmental, growth, and yield processes of crop plants. In: Ajuha LR, Reddy VR, Saseendran SA, Yu Q (eds) Response of crops to limited water: understanding and modeling water stress effects on plant growth processes. American Society of Agronomy/ Crop Science Society of America / Soil Science Society of America, Madison, WI, p 301-356

Ritchie JT, Singh U, Godwin DC, Bowen WT (1998) Cereal growth, development and yield. In: Tsuji GY, Hoogenboom G, Thornton PK (eds) Understanding options for agricultural production. Kluwer, Dordrecht, p 79-98

Scott RK, English SD, Wood DW, Unsworth MH (2009) The yield of sugar beet in relation to weather and length of growing season. J Agric Sci Camb 81:339-347

Sen PK (1968) Estimates of the regression coefficient based on Kendall's tau. J Am Stat Assoc 63:1379-1389

Senay G, Verdin J (2003) Characterization of yield reduction in Ethiopia using a GIS-based crop water balance model. Can J Rem Sens 29:687-692

Shaw RH (1977) Water use and requirements of maize-a

Editorial responsibility: Tim Sparks,

Cambridge, UK review. Agrometeorology of the maize crop. WMO Publication 481, World Meteorological Organization, Geneva, p 119-134

Sibma L (1970) Relation between total radiation and yield of some field crops in the Netherlands. Neth J Agric Sci 18: 125-131

Singletary GW, Banisadr R, Keeling PL (1994) Heat stress during grain filling in maize: effects on carbohydrate storage and metabolism. Aust J Plant Physiol 21:829-841

Spiertz JHJ (1974) Grain growth and distribution of dry matter in the wheat plants as influenced by temperature, light energy and ear size. Neth J Agric Sci 22:207-220

Stone P (2001) The effects of heat stress on cereal yield and quality. In: Basra AS (ed) Crop responses and adaptations to temperature stress. Food Products Press, Binghamton, NY, p 243-291

Stone PJ, Nicolas ME (1995) Effect of timing of heat stress during grain filling on two wheat varieties differing in heat tolerance. I. Grain growth. Aust J Plant Physiol 22: 927-934

Stone PJ, Nicolas ME (1998) The effect of duration of heat stress during grain filling on two wheat varieties differing in heat tolerance: grain growth and fractional protein accumulation. Aust J Plant Physiol 25:13-20

Tadross MA, Hewitson BC, Usman MT (2005) The interannual variability of the onset of the maize growing season over South Africa and Zimbabwe. J Clim 18:3356-3372

Thorne GN, Ford MA (1971) Sink capacity of wheat ears. Rep. Rothamsted Experimental Station, Report for 1970 1:94-95

Upton M (1987) African farm management. Cambridge University Press, Cambridge

Wardlaw IF, Sofield I, Cartwright PM (1980) Factors limiting the rate of dry matter accumulation in the grain of wheat grown at high temperatures. Aust J Plant Physiol 7: $387-400$

White JW, Reynolds MP (2003) A physiological perspective on modeling temperature response in wheat and maize crops. In: White JW (ed) Modeling temperature response in wheat and maize. Proceedings of a Workshop, CIMMYT, El Batán, Mexico, 23-25 April 2001. CIMMYT, Mexico City, p 8-17

Submitted: August 26, 2010; Accepted: December 12, 2010 Proofs received from author(s): March 17, 2011 